\title{
Downregulation of Long Noncoding RNA Gas5 Affects Cell Cycle and Insulin Secretion in Mouse Pancreatic $\beta$ Cells
}

\author{
Feiyan Jin ${ }^{a, b}$ Ning Wang ${ }^{b}$ Yanan Zhu ${ }^{b}$ Lianghui You ${ }^{c}$ Lintao Wang ${ }^{b}$ Wei De ${ }^{b}$ \\ Wei Tang ${ }^{\mathrm{a}, \mathrm{d}}$ \\ aIslet Cell Senescense \& Function Research Laboratory, Jiangsu Province Geriatric Institute, Nanjing, \\ ${ }^{b}$ Department of Biochemistry and Molecular Biology, Nanjing Medical University, Nanjing, 'Nanjing \\ Maternity and Child Health Care Institute, Nanjing Maternity and Child Health Care Hospital Affiliated \\ with Nanjing Medical University, Nanjing, 'Department of Endocrinology, Jiangyin People's Hospital, \\ School of Medicine, Southeast University, Jiangyin, China
}

\section{Key Words}

Gas5 • Insulin secretion • Pdx1 • MafA

\begin{abstract}
Background: Evidence shows that long non-coding RNAs (IncRNAs) are involved in individual development, cell differentiation, cell cycle processes and other important life processes and are closely related to major human diseases, including diabetes. Recent studies have reported that IncRNAs are involved in $\beta$ cell functions and that IncRNA Gas5 levels decreased in T2DM patients' serum. The purpose of this study was to clarify the role of IncRNA Gas5 in mouse $\beta$ cell functions in vitro and in vivo. Methods: IncRNA Gas5 expression in T2DM and normal mouse tissues was analyzed using qRT-PCR. RNAi, qRT-PCR, Annexin V-FITC assays, western blot, GSIS and RIA were performed to detect the effects of IncRNA Gas5 on insulin synthesis and secretion in vitro and in vivo. Results: The IncRNA Gas5 level was significantly decreased in $\mathrm{db} / \mathrm{db}$ mice. However, IncRNA Gas5 expression was relatively high in the pancreas of normal mice. Knockdown of IncRNA Gas5 expression led to cell cycle G1 arrest and impaired insulin synthesis and secretion in Min6 cells. Further, knockdown of IncRNA Gas5 expression in primary isolated islets resulted in decreased expression of insulin gene and transcription factors, Pdx1 and MafA. These results indicate that IncRNA Gas5 might perform as a new regulator, maintaining $\beta$ cell identity and function by affecting insulin synthesis and secretion.
\end{abstract}




\section{Cellular Physiology Cell Physiol Biochem 2017;43:2062-2073

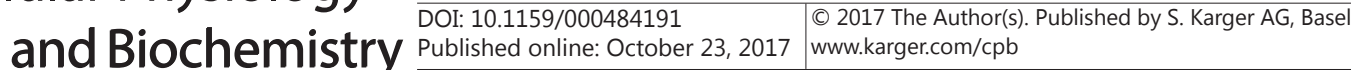 \\ Jin et al.: Gas5 Affects $\beta$ Cells' Cell Cycle and Insulin Secretion}

\section{Introduction}

Pancreatic $\beta$ cells play an important role in maintaining regulation of blood glucose levels because they are the only cell type that can synthesize and secrete insulin in the body [1]. Many studies have found that transcription factors and microRNAs are essential for $\beta$ cell development and function. Their abnormal expression might be related to islet function damage and development of diabetes [2,3]. However, studies investigating links between long noncoding RNAs (lncRNAs), pancreatic $\beta$ cell function, and the development of diabetes have just started.

Noncoding RNA (ncRNA) includes short RNA, such as miRNA, siRNA and piRNA, and long noncoding RNA (lncRNA)[4]. There is no strict limit between short RNA and lncRNA, but the length of the ncRNA nucleotide sequence distinguishes them. In recent years, many studies have shown that IncRNAs regulate protein-coding genes at epigenetic, transcriptional and post-transcription levels and are involved in transcription activation, transcription interference, transcription regulation, and other important regulation processes [4, 5]. IncRNAs are also involved in regulating various processes related to cancer, diabetes, autoimmune diseases and Alzheimer's disease [4]. IncRNA H19 was first reported to be involved in intergenerational transfer of gestational diabetes mellitus (GDM) and in GDM-associated impairments of islet structure and function [6]. Jorge Ferrer [7] and others identified 1128 lncRNAs from human adult islet cells and showed that islet-related lncRNAs were highly specific and subject to the regulation of glucose. Previous studies $[8,9]$ have shown that knockdown of lncRNA TUG1 expression in vivo and in vitro affected apoptosis of islet $\beta$ cells and insulin secretion. IncRNA Meg3 levels were significantly decreased in NOD mice and $\mathrm{db} / \mathrm{db}$ mice islets, and knockdown of lncRNA Meg3 expression, in vivo and in vitro, affected islet $\beta$ cell synthesis and secretion of insulin and increased $\beta$ cell apoptosis. $\beta$-cell long intergenic non-coding RNA 1 ( $\beta$ linc1) is necessary for the specification and function of islet $\beta$ cells. Knockdown of $\beta$ linc1 expression resulted in defection of islet development and impaired glucose homeostasis in adult mice [10]. These results suggest that lncRNAs are involved in islet cell differentiation, development processes and maintaining the function of adult $\beta$ cells. Therefore, identifying additional islet-related lncRNAs and exploring their role in maintaining islet $\beta$ cell function could provide new technologies and ideas for pancreatic $\beta$ cell function and molecular mechanisms of diabetes.

LncRNA Gas5 (growth arrest-specific transcript 5) was originally isolated by a subtractive cDNA library [11]. IncRNA Gas5 is the key regulatory factor in mammalian cell apoptosis and growth, suggesting that lncRNA Gas5 is essential for normal growth and development. lncRNA Gas5 is extensively expressed in various tissues and organs in mice and humans. Mouse lncRNA Gas5 is located on chromosome 1, with a length of 2554 bp. Recent studies have found that human serum IncRNA Gas5 level is correlated with T2DM[12]. However, it is unclear whether lncRNA Gas5 is involved in maintaining the function of adult mouse pancreatic $\beta$ cells.

This study aimed to identify the relationship between lncRNA Gas5 and the function of adult islet cells. We demonstrated that lncRNA Gas5 was highly expressed in pancreatic tissues and downregulated in T2DM mice ( $\mathrm{db} / \mathrm{db}$ mice). Downregulation of IncRNA Gas5 expression in vitro blocked pancreatic $\beta$ cell proliferation and impaired insulin synthesis and secretion. Therefore, IncRNA Gas 5 might serve as a new regulator in pancreatic $\beta$ cell function and T2DM development.

\section{Materials and Methods}

Animals maintenance, islet isolation, and culture

8 weeks old and 12 weeks old db/db male mice ( $\mathrm{n}=20$, body weight, 35-40g), and age-matched C57BL/ KsJ (BKS) mice ( $n=20$, body weight, 20-25g) were purchased from the Model Animal Research Center of Nanjing University. 8 weeks old and 12 weeks old db/db male mice presented hyperglycemia. 8 weeks old 


\section{Cellular Physiology Cell Physiol Biochem 2017;43:2062-2073 \begin{tabular}{l|l|l|l}
\hline DOI: 10.1159/000484191 & $\begin{array}{l}\text { C) } 2017 \text { The Author(s). Published by S. Karger AG, Basel } \\
\text { www.karger.com/cpb }\end{array}$
\end{tabular} Jin et al.: Gas 5 Affects $\beta$ Cells' Cell Cycle and Insulin Secretion}

C57BL/6J male mice ( $\mathrm{n}=20$, weight, 20-25g) were purchased from the Experimental Animal Center of Nanjing Medical University. Mouse handling and experimental procedures were approved by the Ethics Committee for the use of Experimental Animals at Nanjing Medical University.

Pancreatic islets of C57BL/6J mice $(n=20$, weight, 20-25 g) and $\mathrm{db} / \mathrm{db}$ mice were isolated and hand-picked according to previously described methods [3]. Primary islets were cultured in 24-well plates with complete RPMI1640 medium (Invitrogen, Carlsbad, CA) containing $11.1 \mathrm{mM}$ glucose, $10 \mathrm{mM}$ HEPES supplemented with $10 \%$ fetal bovine serum, 100 units / $\mathrm{mL}$ penicillin, and $100 \mathrm{mg} / \mathrm{mL}$ streptomycin for $4 \mathrm{~h}$ to recover from isolation prior to experimental procedures.

\section{Cell culture and siRNA transfection}

Mouse pancreatic $\beta$ cell line Min6 was cultured in Dulbecco's modified Eagle's medium (DMEM) (Invitrogen, Carlsbad, CA) containing $25 \mathrm{mM}$ D-glucose, $10 \mathrm{mM}$ HEPES, $50 \mathrm{mM}$ sodium pyruvate supplemented with 15\% FBS, 100 units $/ \mathrm{mL}$ penicillin, $100 \mathrm{mg} / \mathrm{mL}$ streptomycin, and $50 \mathrm{mmol} / \mathrm{L} \beta$-mercaptoethanol at $37^{\circ} \mathrm{C}$ in $5 \% \mathrm{CO}_{2}$. IncRNA Gas5-specific small interfering RNA (siRNA) (Invitrogen, Carlsbad, CA 10650006) (Table 1) and scrambled siRNA (Invitrogen, Carlsbad, CA 12935300) were designed and synthesized from Invitrogen and transfected to Min 6 cells by Lipofectamine 2000 reagent (Invitrogen, Carlsbad, CA). The final concentration of each siRNA in the transfection sample was $100 \mathrm{nmol} / \mathrm{L}$, according to the manufacturer's instructions. After $48 \mathrm{~h}$ transfection, cells were processed for subsequent experiments. To verify if there were any off-target effects, expression of LncRNA Gas5 was examined using real-time PCR after three Gas5-siRNA mixture transfections, which could effectively avoid off-target effects.

\section{Mouse pancreatic islets Gas5 siRNAs transfection}

Pancreatic islets of C57BL/6J mice were isolated and hand-picked; Mice islets were transferred to 6-well plates (100 islets per well) and cultured in 2 ml RPMI-1640 medium for $24 \mathrm{~h}$; Then, lncRNA Gas5specific small interfering RNA (siRNA) and scrambled siRNA were transfected to isolate primary islets using Lipofectamine 2000 reagent. The final concentration of each siRNA in the transfection sample was 100 $\mathrm{nmol} / \mathrm{L}$, according to the manufacturer's instructions. After $24 \mathrm{~h}$, isolated primary islets were collected for the following experiments.

Glucose treatment of Min6 cells

To study the effects of glucose exposure, Min 6 cells were plated in 6 wells plates $\left(5 \times 10^{5}\right.$ per well $)$ and then assigned to DMEM medium containing 5.5, 11.1, 25, and $33.3 \mathrm{mM}$ glucose for $24 \mathrm{~h}$. At the end of incubation, Min6 cells were harvested for measurement of Gas5 and Ins2 and MafA expression.

Table 1. Primers used for real time PCR and siRNA sequences for lncRNA Gas5

\begin{tabular}{|c|c|}
\hline Primer name & Sequence 5'-3' \\
\hline LncRNA Gas5 forward & CACGTGTTCCATCCTGGTCA \\
\hline LncRNA Gas5 reverse & GTCAAGGAAGCCCACCATCA \\
\hline Ins1 forward & CAATCATAGACCATCAGCAAG \\
\hline Ins1 reverse & AGAAACCACGTTCCCCAC \\
\hline Ins2 forward & CCCAGGCTTTTGTCAAACAG \\
\hline Ins2 reverse & GTGCCAAGGTCTGAAGGTC \\
\hline Pdx1 forward & AGCTCCCTTTCCCGTGGATGAAAT \\
\hline Pdx1 reverse & TAGGCAGTACGGGTCCTCTTGTTT \\
\hline MafA forward & АTCATCACTCTGCССАССАТ \\
\hline MafA reverse & AGTCGGATGACCTCCTCCTT \\
\hline NeuroD forward & CAGGGTTATGAGATCGTC \\
\hline NeuroD reverse & GTTTCTGGGTCTTGGAGT \\
\hline GLUT2 forward & ATCGCCCTCTGCTTCCAGTAC \\
\hline GLUT2 reverse & GAACACGTAAGGCCCAAGGA \\
\hline Nkx6.1 forward & CCGGTCGGACGCCCATC \\
\hline Nkx6.1 reverse & GAGGCTGCCACCGCTCGATTT \\
\hline CyclinD1 forward & CAGAGAGCTACAGACTCCGC \\
\hline CyclinD1 reverse & CACAGGAGCTGGTGTTCCAT \\
\hline CyclinD2 forward & AAGGAGGTAAGGGAAGCACTC \\
\hline CyclinD2 reverse & CCTCGATGGTCAACAGGTTCT \\
\hline CyclinD3 forward & AATGATGGCAGTGGATGGAGC \\
\hline CyclinD3 reverse & CCTTTTGCACGCACTGGAAG \\
\hline CyclinE1 forward & TCCACGCATGCTGAATTATC \\
\hline CyclinE1 reverse & TTGCAAGACCCAGATGAAGA \\
\hline CyclinE2 forward & AAAAAGTCTTGGGCAAGGTAAA \\
\hline CyclinE2 reverse & GCATTCTGACCTGGAACCAC \\
\hline$\beta$-actin forward & TCCTGTGGCATCCACGAAACTACA \\
\hline$\beta$-actin reverse & ACCAGACAGCACTGTGTTGGCATA \\
\hline GAPDH forward & GACTCATGACCACAGTCCATGC \\
\hline GAPDH reverse & AGAGGCAGGGATGATGTTCTG \\
\hline LncRNA Gas5-si-1 sense & CAGUGCCACAAUGAUGACAUCAUAU \\
\hline LncRNA Gas5-si-1 antisense & AUAUGAUGUCAUCAUUGUGGCACUG \\
\hline LncRNA Gas5-si-2 sense & GCUGGAUAGACAGUUUGAAAGGUAA \\
\hline LncRNA Gas5-si-2 antisense & UUACCUUUCAAACUGUCUAUCCAGC \\
\hline LncRNA Gas5-si-3 sense & UAACUGCUGGAUAUGUGCAACUCAA \\
\hline LncRNA Gas5-si-3 antisense & UUGAGUUGCACAUAUCCAGCAGUUA \\
\hline
\end{tabular}




\section{Cellular Physiology Cell Physiol Biochem 2017;43:2062-2073 \begin{tabular}{l|l} 
DOI: 10.1159/000484191 & $\begin{array}{l}\text { (O) 2017 The Author(s). Published by S. Karger AG, Basel } \\
\text { www.karger.com/cpb }\end{array}$
\end{tabular} \\ Jin et al.: Gas5 Affects $\beta$ Cells' Cell Cycle and Insulin Secretion}

\section{RNA extraction and Real-time PCR analyses}

Total RNA was extracted and purified from isolated mouse islets (150 islets for each batch), various tissues from mice and cultured Min 6 cells using TRIzol reagent (Invitrogen) according to the manufacturer's instructions. RNA (1 $\mu \mathrm{g})$ was reverse transcribed to cDNA in a final volume (20 $\mu \mathrm{L})$ by using a Reverse Transcription Kit (Takara, Dalian, China). Real-time PCR analyses were performed with SYBR Premix Ex Taq (Takara, Dalian, China). Mouse $\beta$-actin as an internal control gene was not affected under the glucose treatment experimental conditions. Gene expression was determined by $2^{-\Delta \Delta \mathrm{Ct}}$ methodology, normalized against the $\beta$-actin. All the primer sequences were listed in Table 1. qRT-PCR and data collection were presented using an ABI 7500 real-time PCR system.

\section{Flow cytometry analysis}

Min6 cells transiently transfected with IncRNA Gas5-siRNA were harvested at $48 \mathrm{~h}$ post-transfection by trypsinization. After double-staining with fluorescein isothiocyanate (FITC)-Annexin V and propidium iodide (PI), transfected cells were analyzed by flow cytometry (FACScan, BD Biosciences, San Jose, CA) via Cell Quest software (BD Biosciences). Cells were categorized as viable, dead, early apoptosis, and late apoptosis cells; then, the relative ratio of apoptotic cells was compared to control transfectant from each experiment. Cells for cell cycle analysis were stained with PI using the CycleTEST ${ }^{\text {M }}$ PLUS DNA Reagent Kit (BD Biosciences) following the protocol and analyzed by FACScan. The percentage of cells in G0/G1, S, and G2/M phase were counted and compared.

Measurement of insulin secretion and intracellular insulin protein content

Min6 cells were planted in 48-well plates at $5 \times 10^{4}$ cells per well. After $48 \mathrm{~h}$ transfection, the medium was removed, and cells were washed twice with sterile Krebs Ringer buffer (KRB) containing $115 \mathrm{mM} \mathrm{NaCl}$, $4.7 \mathrm{mM} \mathrm{KCl}, 1.2 \mathrm{mM} \mathrm{MgSO}_{4}, 1.2 \mathrm{mM} \mathrm{KH}_{2} \mathrm{PO}_{4}, 20 \mathrm{mM} \mathrm{NaHCO}_{3}, 16 \mathrm{mM} \mathrm{HEPES}, 2.56 \mathrm{mM} \mathrm{CaCl}_{2}$, and $0.2 \%$ bovine serum albumin (BSA), followed by pre-incubation with $200 \mathrm{ml}$ of the same buffer supplemented with $2 \mathrm{mM}$ glucose at $37^{\circ} \mathrm{C}$ for $1 \mathrm{~h}$. Subsequently, cells were treated for $1 \mathrm{~h}$ in $200 \mu \mathrm{L} \mathrm{KRB}$ buffer containing low $(2 \mathrm{mM})$ or high $(20 \mathrm{mM})$ concentrations of glucose. Supernatants were collected at the indicated time, and insulin concentrations were determined using radioimmunoassay (RIA) according to previously described methods [13]. After transfection for $48 \mathrm{~h}$ (at $25 \mathrm{mM}$ glucose), acid ethanol extraction $(0.15 \mathrm{M} \mathrm{HCl}$ in $75 \%$ ethanol) occurred, and cellular insulin content was detected. These results were normalized to the total protein concentration according to previously described methods [14]. Subsequently, the amount of secreted insulin protein was counted (as a ratio) and compared with total cellular insulin content.

Protein extraction and western blot assay

Min6 cells were lysed using RIPA protein extraction reagent, supplemented with a protease inhibitor (cocktail) and phenylmethylsulfonyl fluoride (PMSF). With protein content determined, western blotting was performed according to previously described methods [15]. The primary antibodies and dilutions were anti-Pdx-1 (dilution of 1:500) and anti-MafA (dilution of 1:200), from Santa Cruz Biotechnology (CA). Target protein levels were normalized to the levels of the control protein, mouse anti- $\beta$-actin (dilution of $1: 1000$ ) from Cell Signaling Technology. The secondary antibody was horseradish peroxidase-conjugated goat antirabbit IgG (dilution of 1:5000), goat anti-mouse IgG (dilution of 1:5000), or mouse anti-goat IgG (dilution of 1:10000) from Beijing Zhong Shan Biotechnology.

\section{Data analysis}

Results are presented as the mean \pm SE. Comparisons were performed using Student's t-test between pairs of groups or ANOVA for more than two groups, followed by Dunnett's multiple comparison. Significance was set at $\mathrm{P}<0.05$, which is indicated in the figures.

\section{Results}

IncRNA Gas5 was relatively high expressed in mouse pancreas and decreased in T2DM mouse models

We used RT-PCR to examine the expression level of lncRNA Gas5 in adult male C57BL/6J mice tissues, including heart, liver, spleen, lung, muscle, and pancreas; pancreas tissue had 
A

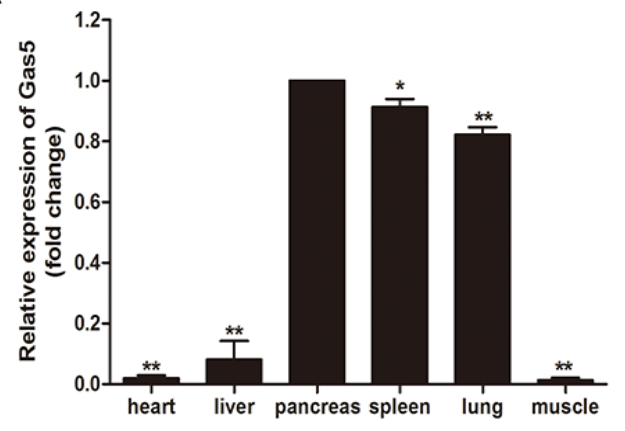

B

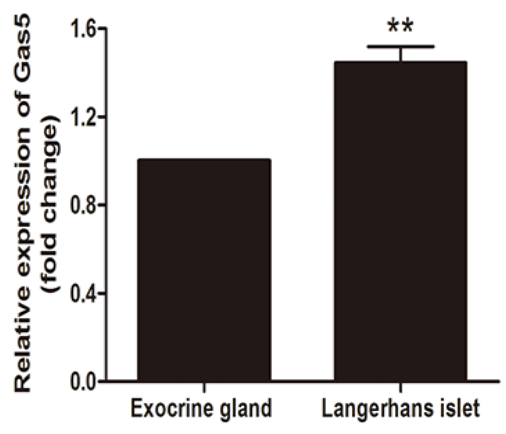

Fig. 1. The abundance of IncRNA Gas5 in different tissues of adult male C57 BL/6 mouse. Equal amounts of RNAs from various C57BL/6 mice tissues (A) and islet preparations and exocrine gland (B) were reverse transcribed and lncRNA Gas5 expression was determined by RT-PCR. Beta-actin was used as an internal control. Values are the means \pm SEM ( $n=3$; pooled samples of multiple tissues and islet of Langerhans); *, $\mathrm{P}<0.05 ; * *, \mathrm{P}<0.01$.

A

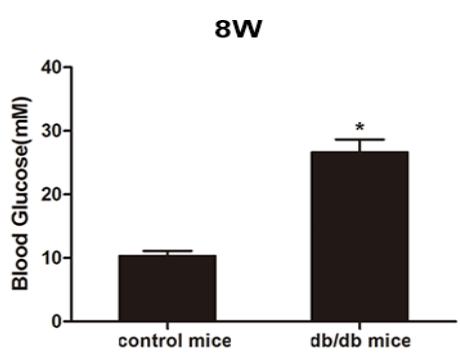

C

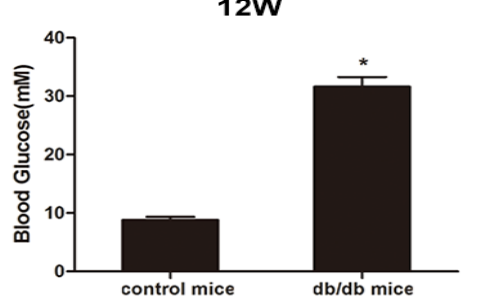

B

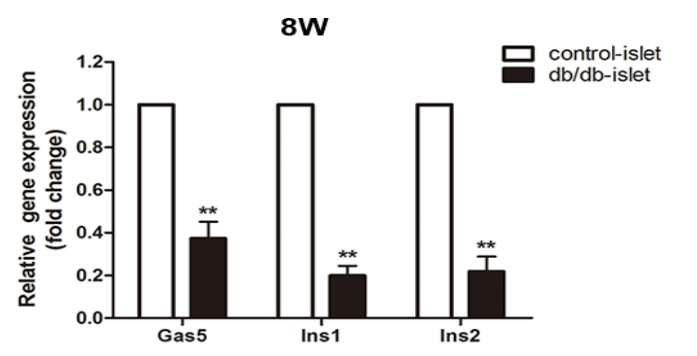

D

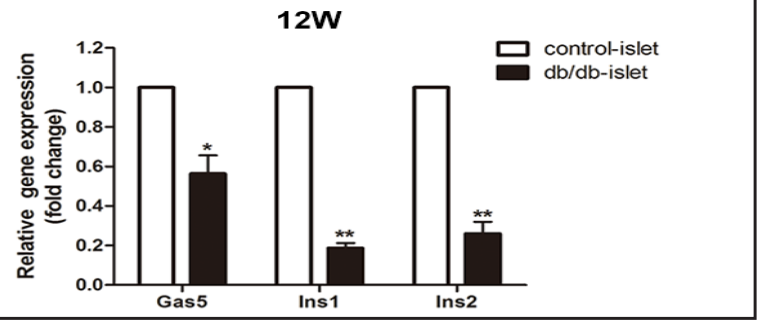

Fig. 2. LncRNA Gas5 levels decreased in $\mathrm{db} / \mathrm{db}$ mice. A and $\mathrm{C}$. Blood glucose were monitored in male control mice and $\mathrm{db} / \mathrm{db}$ mice at 8 weeks old and 12 weeks old $(n=20)$. B and $D$. Total RNA was isolated from the mouse islets and lncRNA Gas5 levels were measured by RT-PCR. Beta-actin was used as an internal control. Values are the means \pm SEM $\left(\mathrm{n}=3\right.$; pooled samples of islet of langerhans). ${ }^{*}, \mathrm{P}<0.05 ;{ }^{* *}, \mathrm{P}<0.01$ vs control mice $8 \mathrm{~W}$ and $12 \mathrm{~W}$.

relatively high lncRNA Gas5 expression (Fig. 1A). After islet isolation, lncRNA Gas5 was primarily expressed in mice pancreatic islet extracts compared to exocrine glands (Fig. 1B).

To determine the potential role of IncRNA Gas5 in the pathogenesis of diabetes, we first examined blood glucose in 8 and 12-week-old control and T2DM mice ( $\mathrm{db} / \mathrm{db}$ mice) (Fig. $2 \mathrm{~A}$ and $\mathrm{C}$ ). Expression of lncRNA Gas5 was detected in 8 and 12 -week-old db/db mice islets. We found that the expression of lncRNA Gas $5 \mathrm{in} \mathrm{db} / \mathrm{db}$ mice islets was less than that in the control mice (Fig. 2B and D). These results suggest that the low expression of lncRNA Gas5 might be related to diabetes.

\section{IncRNA Gas5 was dynamically regulated by glucose}

Previous results showed that the lncRNA Gas5 level was significantly decreased when $\mathrm{db} / \mathrm{db}$ mice were hyperglycemic. Thus, we speculated that decreased lncRNA Gas5 levels 


\section{Cellular Physiology Cell Physiol Biochem 2017;43:2062-2073

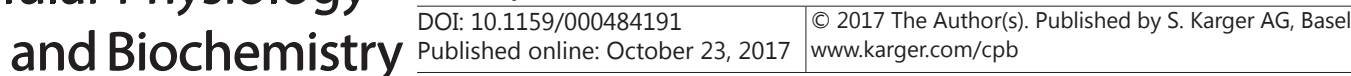

Fig. 3. Expression and glucose-dependent regulation of IncRNA Gas5 mRNA as well as Ins 2 and MafA in Min6 cells. Min6 cells were treated with $5.5,11.1,25,33.3 \mathrm{mM}$ glucose for $24 \mathrm{~h}$. RT-PCR was used to determine lncRNA Gas5 and Ins2 and MafA expression. Beta-actin was used as an internal control. Values are the means \pm SEM of three seperate experiments. *, $\mathrm{P}<0.05$; **, $\mathrm{P}<0.01$ vs $25 \mathrm{mM}$.

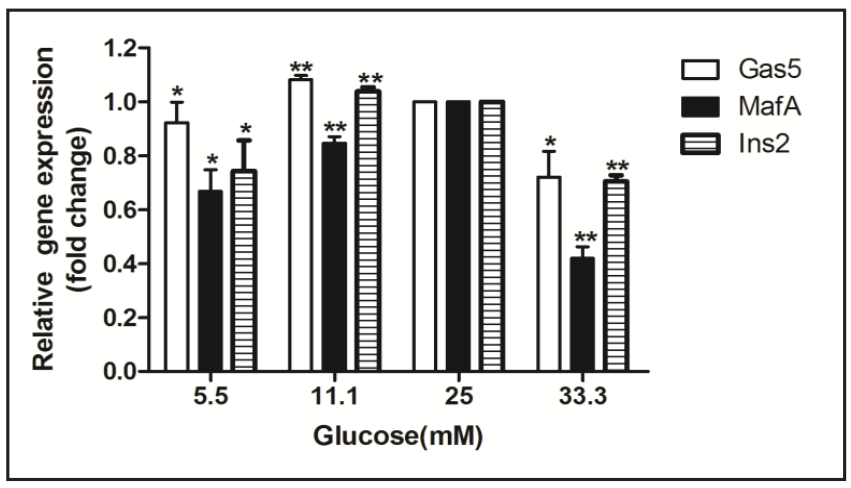

might be related to glucose regulation. To assess whether lncRNA Gas5 is dynamically regulated by glucose, we exposed pancreatic $\beta$ cell Min6 cells to $5.5 \mathrm{mM}, 11.1 \mathrm{mM}, 25 \mathrm{mM}$ and $33.3 \mathrm{mM}$ glucose concentrations for $24 \mathrm{~h}$. In vitro, Min 6 cell glucose-stimulated insulin secretion (GSIS) was appropriately preserved in the presence of $25 \mathrm{mM}$ glucose. We found that expression levels of lncRNA Gas 5 were dynamically regulated by glucose concentrations ranging from $5.5 \mathrm{mM}$ to $33.3 \mathrm{mM}$, correlating with the insulin gene (Ins2) and MafA mRNA levels (Fig. 3A and B). It was noted that high glucose concentration (33.3 mM) suppressed the expression level of IncRNA Gas5. Ins2 was previously reported to be regulated by glucose at the transcriptional level. MafA is a $\beta$-cell-specific and glucose-regulated transcriptional activator for insulin gene expression; thus, it might be involved in the function and development of $\beta$ cells, as well as in the pathogenesis of diabetes $[16,17]$. These results indicate that lncRNA Gas5 is likely to play a role in pancreatic $\beta$ cell function.

Suppression of IncRNA Gas5 expression in Min6 cells induces impairment of GSIS

To determine the influence of IncRNA Gas 5 on pancreatic $\beta$ cell function, we used lncRNA Gas5 siRNA to downregulate lncRNA Gas5 expression and detected its effects on insulin synthesis and secretion. First, to downregulate the expression of IncRNA Gas5, IncRNA Gas5 siRNA (si-1, si-2, si-3) and a negative control sequence (si-NC) were transiently transfected into Min 6 cells. Cells were collected at $48 \mathrm{~h}$ after transfection for detecting lncRNA Gas5 expression. RT-PCR analysis revealed that lncRNA Gas 5 si-3 was the most effective, achieving approximately $50 \%$ reduction compared with si-NC (Fig. 4.1A). The following experiments in Min6 cells and mouse pancreatic primary islets all used lncRNA Gas5 si-3 for knockdown studies.

lncRNA Gas5 siRNA and si-NC were transfected into Min6 cells. After $48 \mathrm{~h}$, we performed the glucose-stimulated insulin secretion (GSIS) assay and detected insulin secretion by RIA. At $2 \mathrm{mM}$ glucose concentration, no obvious differences in secreted insulin concentrations in Min6 calls were observed, whereas insulin secretion was significantly reduced in $20 \mathrm{mM}$ glucose concentration in the IncRNA Gas5 siRNA-treated group (Fig. 4.1B). Impairment of glucose-stimulated insulin secretion might result from a defect in insulin synthesis [18]. We also found a decrease in cellular insulin content in the IncRNA Gas5 siRNA-treated group (Fig. 4.1C).

To determine the function of IncRNA Gas5 in insulin production, insulin gene transcripts Insulin1 (Ins1) and Insulin2 (Ins2) were detected by RT-PCR. Insulin2 was more abundant and was significantly reduced in the lncRNA Gas5 siRNA-treated group (Fig. 4.2A).

To further explain how downregulated IncRNA Gas5 expression impaired insulin production, we quantified several selected transcriptional factors that are known to play a role in pancreatic $\beta$ cell maturation and insulin transcription. These included pancreatic and duodenal homeobox factor $1(\mathrm{Pdx} 1)$, v-maf musculoaponeurotic fibrosarcoma oncogene homologue A (MafA), neurogenic differentiation factor 1 (NeuroD1), NK6 homeobox 1 (Nkx6.1) and glucose transporter 2 (Glut2) at mRNA levels. Except for Nkx6.1, expression was significantly decreased in the lncRNA Gas5 siRNA-treated group (Fig. 4.2B). Particularly, 


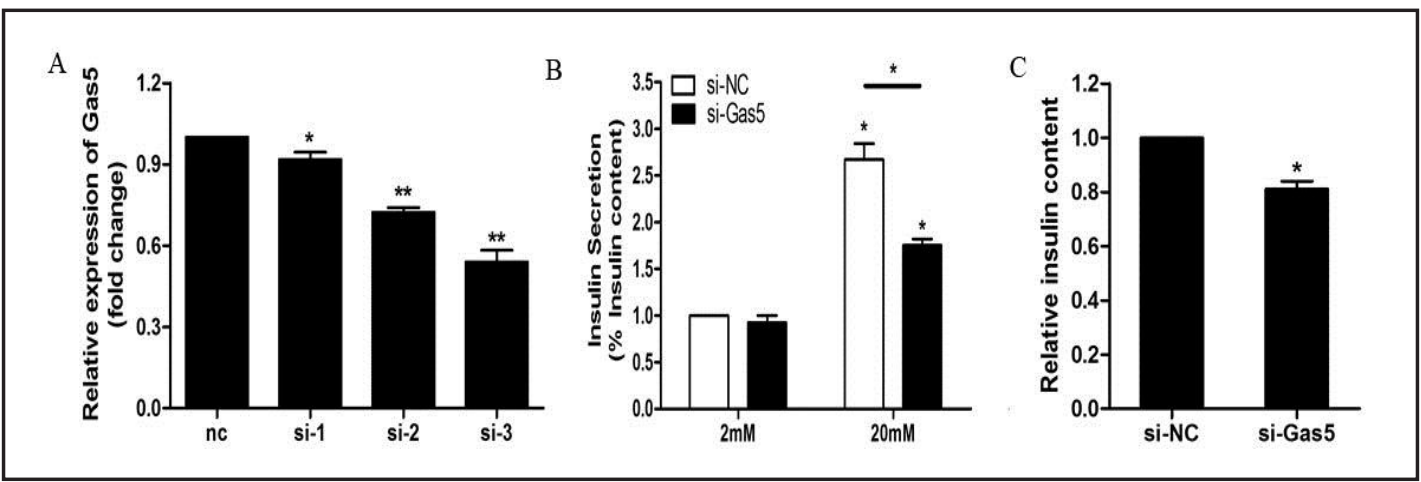

Fig. 4.1. Knockdown of lncRNA Gas5 inhibits insulin synthesis and secretion in vitro. Min6 cells were transfected with IncRNA Gas5-siRNA or a negative control-siRNA using Lipofectamine 2000 for $48 \mathrm{~h}$. A: IncRNA Gas5 levels were determined by RT-PCR. $\beta$-actin was used as an internal control. B: Relative insulin secretion with and without inactivation of lncRNA Gas5 in Min6 cells at $2 \mathrm{mM}$ and $20 \mathrm{mM}$ glucose. Results are expressed as a fold of the value secreted with $2 \mathrm{mM}$. C: Insulin content was measured after acidified ethanol extraction. RIA assay was used to detect insulin content and secretion. Values are the means \pm SEM of three seperate experiments. ${ }^{*}, \mathrm{P}<0.05 ;{ }^{* *}, \mathrm{P}<0.01$ vs si-NC.

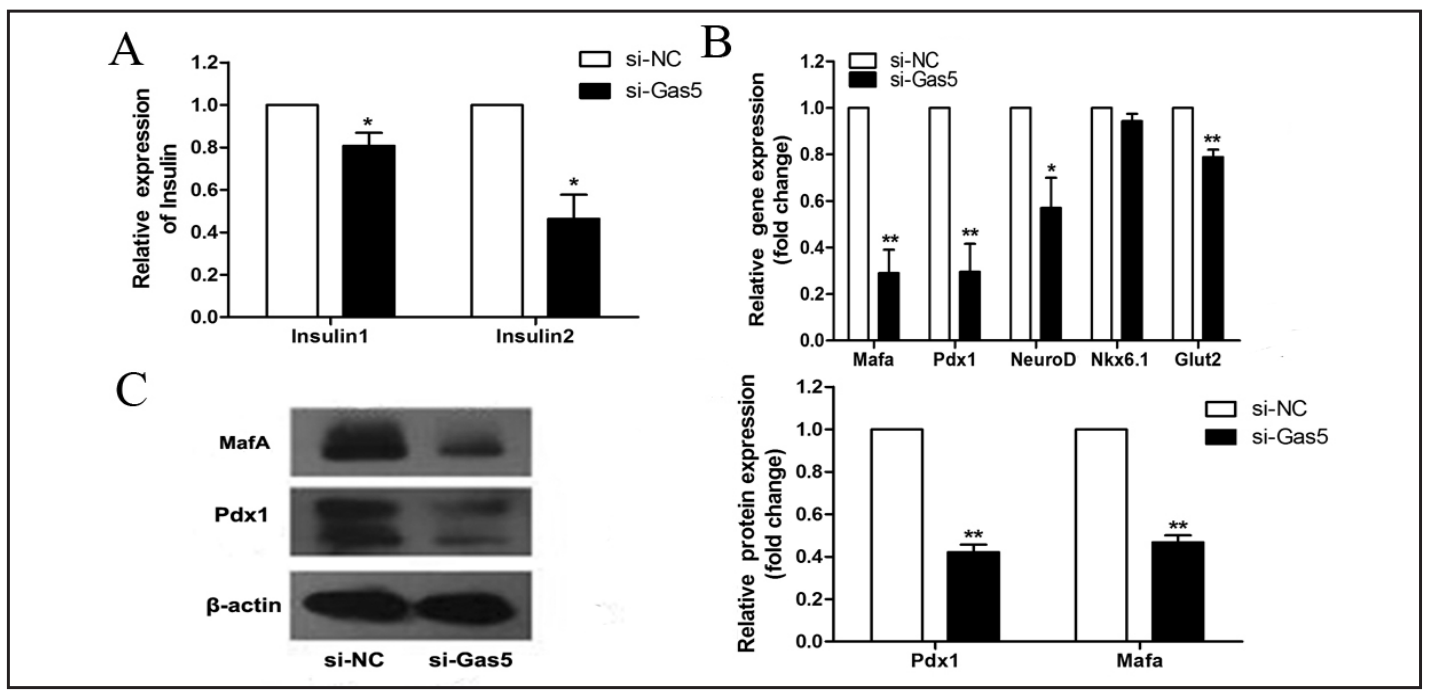

Fig. 4.2. Decreased expression of $\beta$ cell specific transcriptional factors after lncRNA Gas 5 knockdown in vitro. Min6 cells were transfected with IncRNA Gas5-siRNA or a negative control-siRNA using Lipofectamine 2000 for $48 \mathrm{~h}$. A: Insulin gene two transcripts: Insulin1 and Insulin2 were detected by RT-PCR. B: Levels of Pdx1, MafA, NeuroD1, Nkx6.1, Glut2 mRNA were determined by real-time RT-PCR. C: Protein levels of Pdx1(46 kDa), MafA(18 kDa) were determined by immunoblot. $\beta$-actin was used as an internal control. Values are the means \pm SEM of three separate experiments. ${ }^{*}, \mathrm{P}<0.05$; ${ }^{* *}, \mathrm{P}<0.01$ vs si-NC.

inhibition of lncRNA Gas5 expression selectively reduced expression of Pdx1 and MafA in mRNA and protein levels (Fig. 4.2B and C). These results may suggest that lncRNA Gas5 could affect insulin production by regulating several key genes, specifically Pdx1 and MafA.

\section{Effects of downregulation IncRNA Gas5 expression on mouse pancreatic $\beta$ cell proliferation and apoptosis}

To assess the role of IncRNA Gas5 on $\beta$ cell mass, we investigated the effects of downregulated lncRNA Gas5 expression on Min6 cell proliferation and apoptosis. Flowcytometry analysis showed that downregulation of IncRNA Gas5 expression induced cell 
Fig. 5. Downregulation of IncRNA Gas5 affected cell cycle, not cell apoptosis in Min6 cells. Min6 cells were transfected with lncRNA Gas5-siRNA or a negative control-siRNA using Lipofectamine 2000 for 48 h. A. Min6 cells were harvested and cycle distribution was then investigated by flow cytometric analysis. B. Min6 cells were harvested and the apoptosis was investigated using Annexin V/ PI by flow cytometric analysis. UL indicated
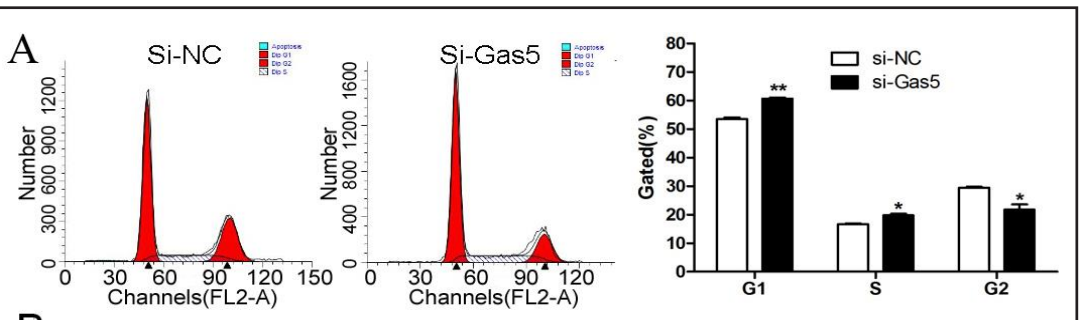

$\mathrm{B}$
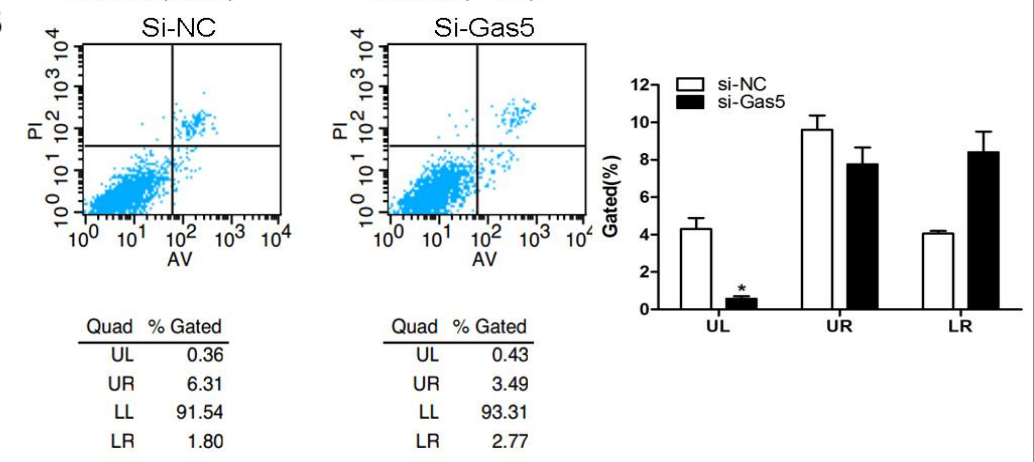
dead cells, UR indicated late apoptosis cells, LL indicated live cells, LR indicated early apoptosis cells. The gated of apoptosis cells was presented in histogram. Values are the means \pm SEM of three separate experiments. * $\mathrm{P}<0.05 ;{ }^{* *}, \mathrm{P}<0.01$ vs si-NC.

Fig. 6. Expression of cell cycle protein in Min6 cells. Min6 cells were transfected with Gas5-siRNA or a negative control-siRNA using Lipofectamine2000 for 48h. mRNA levels of CyclinD1, CyclinD2, CyclinD3, CyclinE1, CyclinE2 were determined by Real-time $\operatorname{PCR}(n=3) . \quad \beta$-actin was used as an internal control. Values are the means \pm SEM of three seperate experiments. *, $\mathrm{P}<0.05$;** $\mathrm{P}<0.01$ vs si-NC.

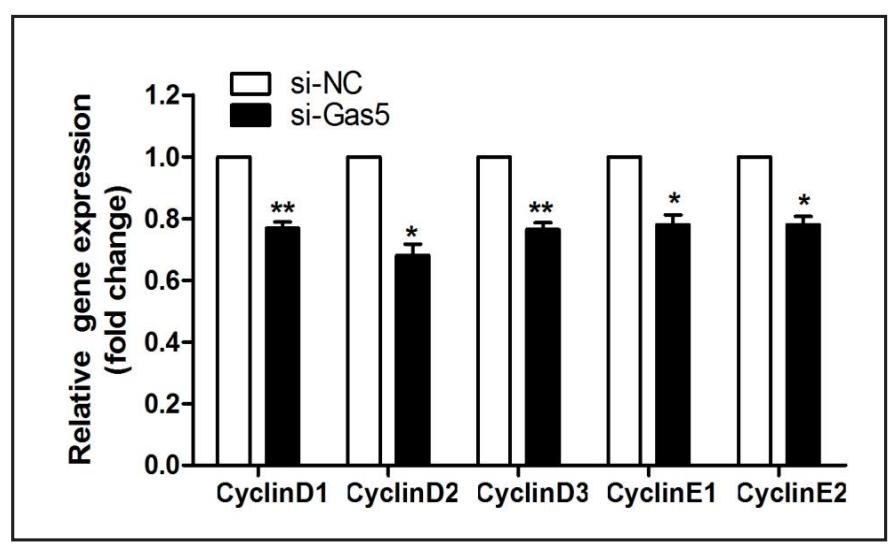

cycle G1/G0 arrest; however, it had no effect on cell apoptosis of Min6 cells (Fig. 5 A and B).

Several genes involved in cell cycle G1/G0 arrest decrease after transfection with IncRNA Gas5 siRNA. We used RT-PCR to detect expression levels of cell cycle proteins, including cyclinD1, cyclinD2, cyclinD3, cyclinE1, and cyclinE2, after transfection with lncRNA Gas5 siRNA. Data showed decreased expression of cyclin proteins (Fig. 6). These results indicate that downregulation of IncRNA Gas5 expression might block pancreatic $\beta$ cell proliferation through cell cycle G1/G0 arrest.

Downregulation of IncRNA Gas5 expression in primary islet of normal mice impairs insulin synthesis

We extracted the normal adult C57BL/6J mice islet. At the primary islet level, using Gas5 siRNAs that were transient transfected blocked lncRNA Gas5 expression, verifying the effects of insulin synthesis at the cellular level. After $48 \mathrm{~h}$ transfection, we detected lncRNA Gas5siRNA interference efficiency by RT-PCR in isolated mouse islets. We found that the lncRNA Gas5 level in the IncRNA Gas5 siRNA-treatment group decreased by $70 \pm 4 \%$ compared with the control group (Fig. 7A). 
Fig. 7. Knockdown of lncRNA Gas5 decreased $\beta$ cell specific transcriptional factors in mouse primary islet. A: RT-PCR data was used to show IncRNA Gas5 expression levels in isolated mouse islet after IncRNA Gas5-siRNA treatment $48 \mathrm{~h} \quad(\mathrm{n}=3$; pooled samples of islet of langerhans). $\beta$-actin was used as an internal control. B-C: Real-time RT-PCR data was used to show Ins1, Ins2, Pdx1, MafA, NeuroD1 mRNA in IncRNA Gas5 siR-

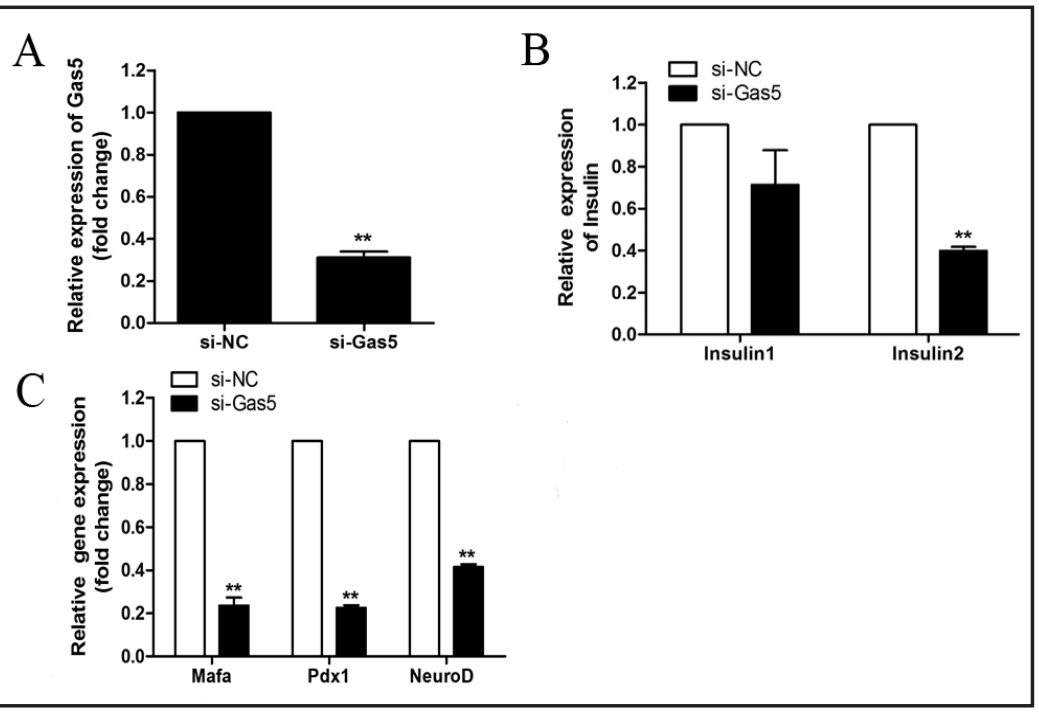
NA-and negative control siRNA-treated islets isolated from C57BL/6 mice ( $n=3$; pooled samples of islet of langerhans). $\beta$-actin was used as an internal control. Values are the means \pm SEM. ${ }^{* *}, \mathrm{P}<0.01$ vs si-NC.

Preliminary experimental results of Min6 cells confirmed that downregulation of lncRNA Gas5 expression caused lower expression of islet-specific transcription factor, leading to the decrease of synthesis and secretion of insulin. Therefore, we examined insulin gene transcription factors Insulin1 (Ins1) and Insulin2 (Ins2) and examined selected islet-specific transcription factors including Pdx1, MafA and NeuroD by RT-PCR in the lncRNA Gas5-siRNA treatment group at the mRNA level. The results showed that Ins2, Pdx1, MafA and NeuroD1 mRNA levels were reduced by $60 \pm 2 \%, 80 \pm 2 \%, 80 \pm 3 \%$, and $50 \pm 7 \%(\mathrm{P}<0.01)$, respectively, in the Gas5-siRNA treatment group (Fig. 7B and C). Pdx1 and MafA decreased more significantly in the IncRNA Gas5-siRNA treatment group, consistent with previous results at the cellular level. This suggests that lncRNA Gas5 might affect insulin gene expression by affecting the expression of specific $\beta$ cell transcription factors, further influencing synthesis of insulin.

\section{Discussion}

lncRNAs are involved in regulating protein-coding gene expression in the form of RNA in epigenetic, transcriptional regulation and post-transcription levels involved in cell development [19], cell cycle [20], cell survival, cell differentiation and other important regulation processes. IncRNAs are also involved in regulating various pathological processes, such as cancer, diabetes, autoimmune diseases and Alzheimer's disease [21, 22]. Recent studies [23] showed that the effects of the IncRNA NONRATT021972 small interfering RNA (siRNA) on dysfunction of hepatic GK through AKT signaling in T2DM rats indicated that lncRNA NONRATT021972 siRNA might have beneficial effects on T2DM. One study [24] investigated the function of $\beta$ cell-specific lncRNAs and transcription factors using transcription factor knockdowns and co-expression network analysis. The results indicated that lncRNAs regulate $\beta$ cell-specific transcription factor networks. Our results indicate that further study of IncRNA's role in physiological and pathological processes of organisms, as well as its its mechanism of action, not only could increase our understanding of physiological and pathological processes but also could provide new ideas and solutions for disease prevention, diagnosis, and treatment.

This study demonstrates that lncRNA Gas5 had relatively high expression in C57BL/6 mouse pancreatic tissue compared to heart, liver, spleen, lung, or muscle tissues (Fig. 1A). This might be related to pancreatic islet function. Further, lncRNA Gas5 level was 


\section{Cellular Physiology Cell Physiol Biochem 2017;43:2062-2073 and BiOChemistry Published online: October 23, 2017 \begin{tabular}{l|l} 
DOI: 10.1159/000484191 2017 The Author(s). Published by S. Karger AG, Basel \\
www.karger.com/cpb
\end{tabular} \\ Jin et al.: Gas5 Affects $\beta$ Cells' Cell Cycle and Insulin Secretion}

significantly decreased in T2DM mice (db/db mice) compared with control mice (Fig. 2 B and D). Therefore, we speculated that the decreased expression of lncRNA Gas5 in T2DM mice is likely involved in pancreatic $\beta$ cell mass reduction or function defect in diabetes.

Glucose was a primary stimulating factor for maintaining pancreatic $\beta$ cell function, which can regulate insulin gene expression and biosynthesis [25]. Dysfunction of pancreatic $\beta$ cells played an important role in the pathogenic process of T1DM and T2DM. Insulin biosynthesis was regulated at the transcription and translation level [26]. The $\beta$ cell ability of rapid response to intracellular signals was mainly due to transcriptional regulation. The numerous discrete sequence elements in insulin gene promoter regions were named the $\mathrm{A}, \mathrm{C}$, $\mathrm{E}, \mathrm{Z}$ and CRE elements, which determined the location of $\beta$ cell insulin and provided binding sites for several types of $\beta$ cell transcription factors that regulate insulin gene expression [27]. Islet-specific transcription factors Pdx1, MafA and NeuroD1 can combine with insulin gene promoter regions, regulating insulin gene transcription and thus affecting the synthesis and secretion of insulin. In this study, we used small interference RNA to knockdown expression of lncRNA Gas 5 at the cell line and primary islet levels, and we detected its effect on pancreatic $\beta$ cell function. The results showed reduced biosynthesis and secretion of insulin. Isletspecific transcription factors and glucose transporter GLUT2, which are related to insulin secretion mRNA levels, were also reduced. Pdx1 and MafA were significantly decreased at the mRNA and protein levels. Pdx1 plays an important role in pancreas development and adult $\beta$ cell function. Studies showed that [28] in the pancreas, MafA was specifically expressed in mature $\beta$ cells. Islet transcriptome analysis, after MafA knockout, revealed that MafA was necessary for several $\beta$ cell-related key molecules, such as Glut2 and CyclinD2. GLUT2 primarily exists in the liver, small intestine, kidney, and pancreatic islet $\beta$ cells. In islet $\beta$ cells, GLUT2 is necessary to stimulate insulin secretion of glucose [29]. From this, we conclude that IncRNA Gas5 affected insulin synthesis processes through insulin gene and islet-specific transcription factor regulation and could also influence the course of insulin secretion via glucose transporter regulation.

LncRNA Gas5 was the key regulatory factor of mammalian cell apoptosis and growth. In this study, we demonstrated that downregulation of lncRNA Gas5 expression resulted in cell cycle G1 arrest in pancreatic Min6 $\beta$ cell lines. Previous studies [30] showed that cyclinD2 was a key factor in $\beta$ cell proliferation in normal postnatal mice. CyclinD2 was necessary for adult mice glucose metabolism and normal postnatal islet growth. CyclinD3 or E cycle protein in $\beta$ cell development could compensate for CyclinD2 and D1[31]. In this study, we found that inhibition of lncRNA Gas 5 expression in Min6 cells could make cyclinD1, cyclinD2, cyclinD3, cyclinE1, and cyclinE2 mRNA levels decrease. Among these, CyclinD1 and CyclinD2 were significantly reduced. This suggests that downregulation of IncRNA Gas5 expression in Min 6 cells caused pancreatic $\beta$ cell cycle G1 phase arrest, which might be mediated by D-cell cycle protein pathways. Further studies are needed to determine mechanisms for regulating the cell cycle.

\section{Conclusion}

We report for the first time that lncRNA Gas5 may play a role in regulating pancreatic $\beta$ cell function. In addition, this study identified lncRNA Gas5 as a novel regulator of insulin synthesis and secretion in pancreatic $\beta$ cells. We demonstrated that the expression of lncRNA Gas5 decreased in T2DM mice, suggesting that lncRNA Gas5 might be involved in pathogenesis of T2DM. It should be noted that inhibition of IncRNA Gas5 affected insulin production by decreasing the expression of islet-specific transcription factors, including Pdx1 and MafA. Therefore, downregulation of lncRNA Gas5 because of hyperglycemia might partly bring about $\beta$ cell dysfunction and could be involved in diabetes pathogenesis. In the future, IncRNA Gas 5 could be used as a new target for the diagnosis and research of diabetes. 


\section{Cellular Physiology Cell Physiol Biochem 2017;43:2062-2073 and Biochemistry Published online: October 23, 2017 l $\begin{aligned} & \text { (c) } 2017 \text { The Author(s). Published by S. Karger AG, Basel } \\ & \text { www.karger.com/cpb }\end{aligned}$ Jin et al.: Gas5 Affects $\beta$ Cells' Cell Cycle and Insulin Secretion}

\section{Acknowledgements}

This study was supported by grants from the National Natural Science Foundation of China (81370920), National Natural Science Foundation of China (81770773), Natural Science Foundation of Jiangsu Province (BK20131110), Natural Science Foundation of Jiangsu Province (BK20171499), Project of "Six Talents Peak of Jiangsu province (2013WSN023)", Jiangsu Province's Key Medical Talents (co-construction) Program,Talent project of "333" project in Jiangsu Province. Jiangsu Province Official Hospital Scientific Research Initial Funding (RPF201501). Jiangsu Province Official Hospital Talents Construction Fund Research Project (IR2015101).

\section{Disclosure Statement}

The authors declare that they have no conflict of interest.

\section{References}

1 Gu G, Wells JM, Dombkowski D, Preffer F, Aronow B, Melton DA: Global expression analysis of gene regulatory pathways during endocrine pancreatic development. Development 2004;131:165-179.

2 Guo S, Dai C, Guo M, Taylor B, Harmon JS, Sander M, Robertson RP, Powers AC, Stein R: Inactivation of specific beta cell transcription factors in type 2 diabetes. J Clin Invest 2013;123:3305-3316.

3 Xu G, Chen J, Jing G, Shalev A: Thioredoxin-interacting protein regulates insulin transcription through microRNA-204. Nat Med 2013;19:1141-1146.

4 Batista PJ, Chang HY: Long noncoding RNAs: Cellular address codes in development and disease. Cell 2013;152:1298-1307.

5 Fatica A, Bozzoni I: Long non-coding RNAs: New players in cell differentiation and development. Nat Rev Genet 2014;15:7-21.

6 Ding GL, Wang FF, Shu J, Tian S, Jiang Y, Zhang D, Wang N, Luo Q, Zhang Y, Jin F, Leung PC, Sheng JZ, Huang HF: Transgenerational glucose intolerance with Igf2/H19 epigenetic alterations in mouse islet induced by intrauterine hyperglycemia. Diabetes 2012;61:1133-1142.

7 Moran I, Akerman I, van de Bunt M, Xie R, Benazra M, Nammo T, Arnes L, Nakic N, Garcia-Hurtado J, Rodriguez-Segui S, Pasquali L, Sauty-Colace C, Beucher A, Scharfmann R, van Arensbergen J, Johnson PR, Berry A, Lee C, Harkins T, Gmyr V, Pattou F, Kerr-Conte J, Piemonti L, Berney T, Hanley N, Gloyn AL, Sussel L, Langman L, Brayman KL, Sander M, McCarthy MI, Ravassard P, Ferrer J: Human beta cell transcriptome analysis uncovers IncRNAs that are tissue-specific, dynamically regulated, and abnormally expressed in type 2 diabetes. Cell Metab 2012;16:435-448.

>8 Yin DD, Zhang EB, You LH, Wang N, Wang LT, Jin FY, Zhu YN, Cao LH, Yuan QX, De W, Tang W: Downregulation of lncRNA TUG1 affects apoptosis and insulin secretion in mouse pancreatic beta cells. Cell Physiol Biochem 2015;35:1892-1904.

>9 You L, Wang N, Yin D, Wang L, Jin F, Zhu Y, Yuan Q De W: Downregulation of long noncoding RNA meg3 affects insulin synthesis and secretion in mouse pancreatic beta cells. J Cell Physiol 2016;231:852-862.

10 Arnes L, Akerman I, Balderes DA, Ferrer J, Sussel L: Betalinc1 encodes a long noncoding RNA that regulates islet beta-cell formation and function. Genes Dev 2016;30:502-507.

11 Coccia EM, Cicala C, Charlesworth A, Ciccarelli C, Rossi GB, Philipson L, Sorrentino V: Regulation and expression of a growth arrest-specific gene (gas5) during growth, differentiation, and development. Mol Cell Biol 1992;12:3514-3521.

12 Carter G, Miladinovic B, Patel AA, Deland L, Mastorides S, Patel NA: Circulating long noncoding RNA GAS5 levels are correlated to prevalence of type 2 diabetes mellitus. BBA Clin 2015;4:102-107.

-13 Poy MN, Hausser J, Trajkovski M, Braun M, Collins S, Rorsman P, Zavolan M, Stoffel M: MiR-375 maintains normal pancreatic alpha- and beta-cell mass. Proc Natl Acad Sci U S A 2009;106:5813-5818.

14 Lin Y, Sun Z: Antiaging gene Klotho enhances glucose-induced insulin secretion by up-regulating plasma membrane levels of TRPV2 in MIN6 beta-cells. Endocrinology 2012;153:3029-3039. 


\section{Cellular Physiology Cell Physiol Biochem 2017;43:2062-2073 \begin{tabular}{l|l|l} 
DOI: 10.1159/000484191 & $\begin{array}{l}\text { O 2017 The Author(s). Published by S. Karger AG, Basel } \\
\text { www.karger.com/cpb }\end{array}$
\end{tabular} \\ Jin et al.: Gas 5 Affects $\beta$ Cells' Cell Cycle and Insulin Secretion}

15 Sun M, Xia R, Jin F, Xu T, Liu Z, De W, Liu X: Downregulated long noncoding RNA MEG3 is associated with poor prognosis and promotes cell proliferation in gastric cancer. Tumour Biol 2014;35:1065-1073.

16 Bensellam M, Van Lommel L, Overbergh L, Schuit FC, Jonas JC: Cluster analysis of rat pancreatic islet gene mRNA levels after culture in low-, intermediate- and high-glucose concentrations. Diabetologia 2009;52:463-476.

17 Kataoka K, Han SI, Shioda S, Hirai M, Nishizawa M, Handa H: MafA is a glucose-regulated and pancreatic beta-cell-specific transcriptional activator for the insulin gene. J Biol Chem 2002;277:49903-49910.

18 Takamoto I, Kubota N, Nakaya K, Kumagai K, Hashimoto S, Kubota T, Inoue M, Kajiwara E, Katsuyama H, Obata A, Sakurai Y, Iwamoto M, Kitamura T, Ueki K, Kadowaki T: TCF7L2 in mouse pancreatic beta cells plays a crucial role in glucose homeostasis by regulating beta cell mass. Diabetologia 2014;57:542-553.

19 Klattenhoff CA, Scheuermann JC, Surface LE, Bradley RK, Fields PA, Steinhauser ML, Ding H, Butty VL, Torrey L, Haas S, Abo R, Tabebordbar M, Lee RT, Burge CB, Boyer LA: Braveheart, a long noncoding RNA required for cardiovascular lineage commitment. Cell 2013;152:570-583.

20 Meola N, Pizzo M, Alfano G, Surace EM, Banfi S: The long noncoding RNA Vax2os1 controls the cell cycle progression of photoreceptor progenitors in the mouse retina. RNA 2012;18:111-123.

21 Knauss JL, Sun T: Regulatory mechanisms of long noncoding RNAs in vertebrate central nervous system development and function. Neuroscience 2013;235:200-214.

22 Peng X, Gralinski L, Armour CD, Ferris MT, Thomas MJ, Proll S, Bradel-Tretheway BG, Korth MJ, Castle JC, Biery MC, Bouzek HK, Haynor DR, Frieman MB, Heise M, Raymond CK, Baric RS, Katze MG: Unique signatures of long noncoding RNA expression in response to virus infection and altered innate immune signaling. MBIO 2010;1

-23 Song M, Zou L, Peng L, Liu S, Wu B, Yi Z, Gao Y, Zhang C, Xu H, Xu Y, Tang M, Wang S, Xue Y, Jia T, Zhao S, Liang S, Li G: LncRNA NONRATT021972 siRNA normalized the dysfunction of hepatic glucokinase through AKT signaling in T2DM rats. Endocr Res 2017:1-11.

-24 Akerman I, Tu Z, Beucher A, Rolando DM, Sauty-Colace C, Benazra M, Nakic N, Yang J, Wang H, Pasquali L, Moran I, Garcia-Hurtado J, Castro N, Gonzalez-Franco R, Stewart AF, Bonner C, Piemonti L, Berney T, Groop L, Kerr-Conte J, Pattou F, Argmann C, Schadt E, Ravassard P, Ferrer J: Human Pancreatic beta Cell IncRNAs Control Cell-Specific Regulatory Networks. Cell Metab 2017;25:400-411.

25 Schuit F, Flamez D, De Vos A, Pipeleers D: Glucose-regulated gene expression maintaining the glucoseresponsive state of beta-cells. Diabetes 2002;51:S326-S332.

26 Fu Z, Gilbert ER, Liu D: Regulation of insulin synthesis and secretion and pancreatic Beta-cell dysfunction in diabetes. Curr Diabetes Rev 2013;9:25-53.

27 Hay CW, Docherty K: Comparative analysis of insulin gene promoters: Implications for diabetes research. Diabetes 2006;55:3201-3213.

28 Eto K, Nishimura W, Oishi H, Udagawa H, Kawaguchi M, Hiramoto M, Fujiwara T, Takahashi S, Yasuda K: MafA is required for postnatal proliferation of pancreatic beta-cells. Plos One 2014;9:e104184.

29 Thorens B: GLUT2, glucose sensing and glucose homeostasis. Diabetologia 2015;58:221-232.

-30 Georgia S, Bhushan A: Beta cell replication is the primary mechanism for maintaining postnatal beta cell mass. J Clin Invest 2004;114:963-968.

-31 Kozar K, Ciemerych MA, Rebel VI, Shigematsu H, Zagozdzon A, Sicinska E, Geng Y, Yu Q, Bhattacharya S, Bronson RT, Akashi K, Sicinski P: Mouse development and cell proliferation in the absence of D-cyclins. Cell 2004;118:477-491. 